\title{
軍馬補充部保管馬の運動竝 飼料量の基準に關する研究
}

\author{
軍馬補充部三本木支部々員
}

陸軍一等獸醫和田保

目次海

1. 緒言

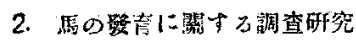

(1) 軍馬補齐部在部間の势

(2) 部隐裸充後の發充

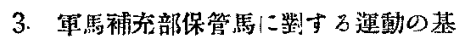

4. 阿料量の基準碀究

5. 柌科の配合及詒理

(1) 解料の配合

(2) 的司粗の浬

6. 結 諭

1 緒

言

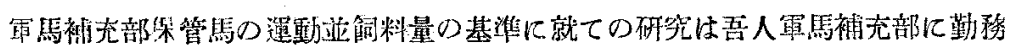

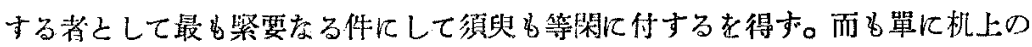

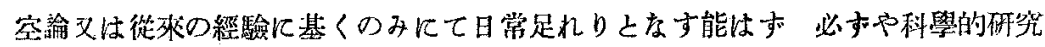

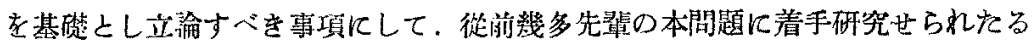



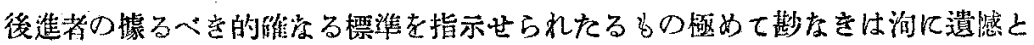
するとてろにして 特に䬲料量の基淮の如を脜交献を徽するも他動物に就ては詳



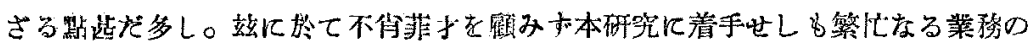

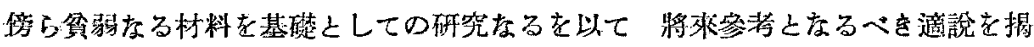

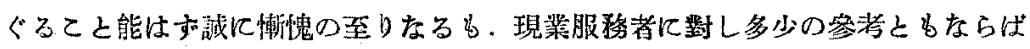

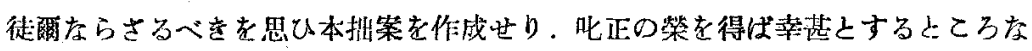
bo

\section{2 馬の聎育に關する調查㸴究}

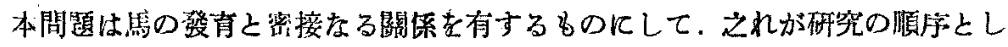

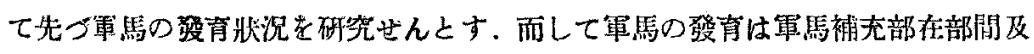
部榢被充後の 2 期に大别するを得へし。






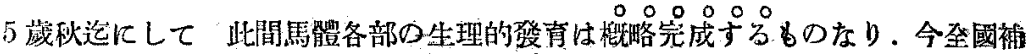

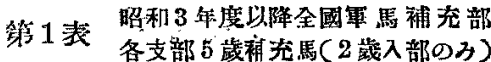

\begin{tabular}{|c|c|c|c|c|c|c|c|}
\hline \multirow{2}{*}{ 年次別 } & \multirow{2}{*}{ 程 } & \multirow{2}{*}{ 斯。 } & \multirow{2}{*}{ 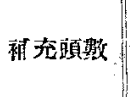 } & \multicolumn{3}{|l|}{ 鳁 } & \multirow{2}{*}{$\frac{\text { 軆 }}{\text { 入部時 }}$} \\
\hline & & & & 入 部時 & 補売 時 & 入部時對增 & \\
\hline \multirow{4}{*}{$\begin{array}{c}\text { 昭 } \\
\text { 和 } \\
3 \\
\text { 年 } \\
\text { 度 }\end{array}$} & 輍 & 種 & 483 & 140.6 & 153.1 & 32.5 & 3.9 .5 \\
\hline & 中 間 & 種 & 902 & 140.0 & 153.4 & 13.4 & 307.7 \\
\hline & 重 & 種 & 166 & 136.7 & 152.] & 15.4 & 282.0 \\
\hline & 計 尔 & 均 & 1.551 & 139.9 & 153.2 & 13.3 & 308.1 \\
\hline \multirow{4}{*}{$\begin{array}{c}\text { 昭 } \\
\text { 和 } \\
4 \\
\text { 年 } \\
\text { 废 }\end{array}$} & 䡛 & 種 & 516 & 140.3 & 152.5 & 12.2 & $=321.3$ \\
\hline & 中 間 & 種 & 945 & 139.4 & 125.6 & 13.2 & 300,3 \\
\hline & 重 & 種 & 66 & 137.5 & 152.8 & 15.3 & 299,5 \\
\hline & 計. 本 & 均 & 1,527 & 139.6 & 152.6 & 13.0 & 307,4 \\
\hline \multirow{4}{*}{$\begin{array}{l}\text { 昭 } \\
\text { 和 } \\
5 \\
\text { 年 } \\
\text { 度 }\end{array}$} & 輊 & 種 & 538 & 141.4 & 152.2 & 10.8 & 326.0 \\
\hline & 中 間 & 種 & 922 & $139.3^{!}$ & 152.9 & 13.6 & 304,0 \\
\hline & 重 & 種 & 33 & 138.2 & 152.3 & 14.1 & 300.0 \\
\hline & 嘼 4 & 均 & 1,488 & 140.0 & 152.6 & 12.6 & $3: 2,0$ \\
\hline
\end{tabular}

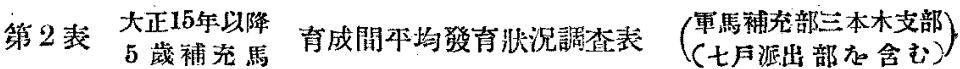

\begin{tabular}{|c|c|c|c|c|c|c|c|c|c|}
\hline \multirow{2}{*}{$\begin{array}{l}\text { 補 } \\
\text { 年 }\end{array}$} & \multirow{2}{*}{$\begin{array}{l}\text { 充 } \\
\text { 度 }\end{array}$} & \multirow{2}{*}{$\begin{array}{l}\lambda \\
\text { 年 }\end{array}$} & \multirow{2}{*}{$\begin{array}{l}\text { 部 } \\
\text { 筩 }\end{array}$} & \multicolumn{2}{|l|}{ 體 } & 高 & \multicolumn{2}{|l|}{ 骷 } & 䆙 \\
\hline & & & & 第 1 年 & 第 2 年 & 第 3 年 & 第 1 占 & 第 2 i & 第3 年 \\
\hline 大正 & 15 & & 2 & 5.0 & 3.3 & 3.0 & $61.2^{\mathrm{G}}$ & $\begin{array}{c}\text { 禖 } \\
26.9\end{array}$ & 34.9 \\
\hline 昭 和 & 2. & & 2 & 5.0 & 4.1 & 2.6 & 50.0 & 41.0 & 40.0 \\
\hline$"$ & 3 & & 2 & 5.0 & 3.7 & $2.3^{1}$ & 49.0 & 22.6 & 42.0 \\
\hline " & 4 & & 2 & 6.4 & 3.4 & 2.7 & 53.0 & 27.0 & 43.6 \\
\hline " & 5 & & 2 & 5.0 & $\mathbf{8 . 1}$ & 2.8 & 55.3 & 37.8 & 33.3 \\
\hline '" & 6 &  & 2 & 6.4 & 3.1 & 2.8 & 69.6 & 38.5 & 41.1 \\
\hline 平 & 均 & & & 5.5 & 3.5 & 2.7 & 55.1 & 32.3 & 39.5 \\
\hline
\end{tabular}

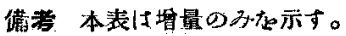




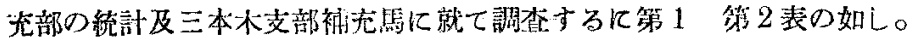

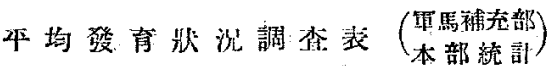

\begin{tabular}{|c|c|c|c|c|c|c|c|}
\hline \multicolumn{2}{|r|}{ 重 } & \multicolumn{2}{|l|}{ 胸 } & 圍 & \multicolumn{2}{|l|}{ 管 } & 国 \\
\hline 啸充特 & 入部時對墙 & 大部时 & 補充時 & 入部胿 & 入部時 & 補充時 & 入部楾: \\
\hline 449.3 & 129.8 & $\begin{array}{r}153.3 \\
\end{array}$ & 172.8 & 19.5 & 17,4 & 18.9 & $\begin{array}{r}1.5 \\
1.5\end{array}$ \\
\hline 465.8 & 158.1 & 150.6 & 174.1 & 23.5 & 17.5 & 39.7 & 2.2 \\
\hline 492.1 & 210.1 & 48.0 & 179.8 & 31.8 & 17.9 & 20.4 & 2,5 \\
\hline 463.7 & 355.5 & 351.2 & 174.3 & 23.1 & 17.5 & 19.5 & 2.0 \\
\hline 456.8 & 135.5 & 151.1 & 371.5 & 20.4 & 17.3 & 19.0 & 1.7 \\
\hline 468.3 & 168.0 & 149.4 & 175.2 & 25.8 & 17.5 & 19.7 & 2.2 \\
\hline 496.8 & 197.3 & 152.4 & 179.2 & 26.8 & 18.1 & $20.9^{\circ}$ & 2.8 \\
\hline 465.6 & 158.2 & 150.0 & 174.1 & 24.1 & 17.4 & 19.5 & 2.1 \\
\hline 454.0 & 128.0 & $153.0^{3}$ & 173.6 & 20.6 & 17.3 & 19.1 & 1.8 \\
\hline 475.0 & 171.0 & 150.4 & $176.3^{\prime}$ & 25.9 & 17.4 & 19.7 & 2.2 \\
\hline 501.0 & 201.0 & 147.7 & 377.8 & $30.1^{\prime \prime}$ & 17.9 & 20.6 & 2.7 \\
\hline 468.0 & 156.0 & .51 .2 & 175.4 & 24.2 & 17.3 & 19.5 & 2.2 \\
\hline
\end{tabular}



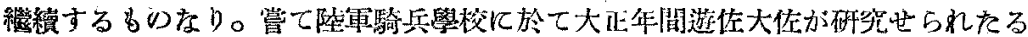


停止する



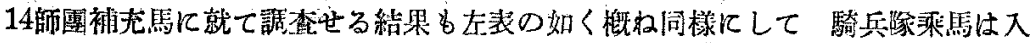

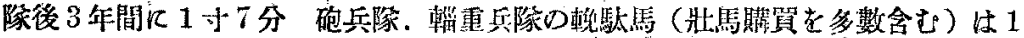

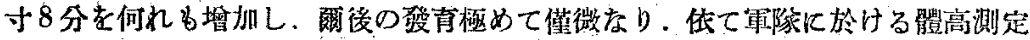

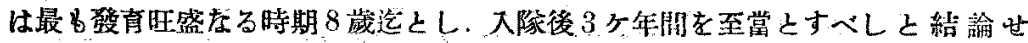

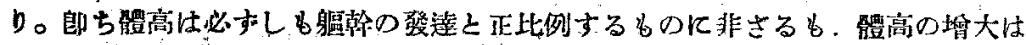

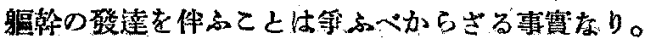




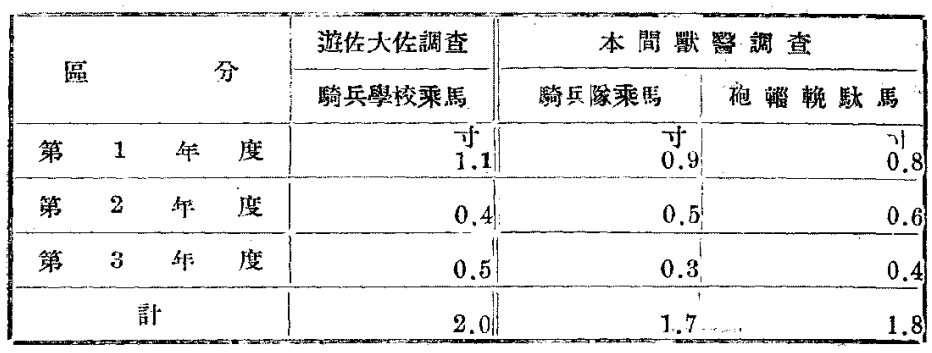



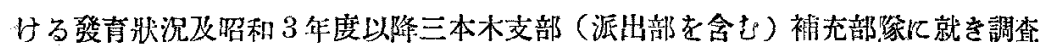
するに，第 3 表及第 4 表の如く補充 1 年後に於ける體高の增扗は何れ女總平均 3

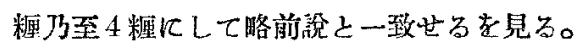

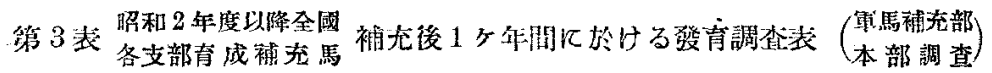

\begin{tabular}{|c|c|c|c|c|c|c|c|c|c|c|}
\hline \multirow{2}{*}{\multicolumn{2}{|c|}{ 補充! 役種 }} & \multirow{2}{*}{$\begin{array}{l}\text { 入部時 } \\
\text { 年 齔 }\end{array}$} & \multirow{2}{*}{ 頚數 } & \multicolumn{2}{|r|}{ 高 } & 䠅 重 & 電 & 圍 & \multirow{2}{*}{\multicolumn{2}{|c|}{  }} \\
\hline & & & & 燳陵 1 年 & 㙁 & 入封 1 㿟 & 增全隊 1 年 & 霄 & & \\
\hline \multirow{6}{*}{$\begin{array}{c}\text { 炤 } \\
\text { 利 } \\
2 \\
\text { 年 } \\
\text { 度 }\end{array}$} & \multirow{3}{*}{$\begin{array}{l}\text { 乘 } \\
\text { 馬 }\end{array}$} & 2 踏 & 1,067 & 1.531 .55 & 朄 & 419468 & $49,1.741 .78$ & & 19.10 .6 & \\
\hline & & 3 藏 & 214 & $1.51 \mid 1.54$ & 3 & 410458 & \begin{tabular}{l|l|l|} 
& & \\
43 & 1.72 & .77
\end{tabular} & 5 & 19.3 & \\
\hline & & 計及本坞 & 1,281 & $1.53,1.56$ & 3 & 417466 & $49,1.741 .78$ & 4 & 199. & 0 \\
\hline & \multirow{3}{*}{ 輓 } & 2 歳 & 609 & 1.531 .57 & 4 & 459,502 & 43 & 5 & & \\
\hline & & 3 筬 & & 1.54 & 3 & 448,496 & 481.761 .82 & 6 & 19. & \\
\hline & & 計及桩边 & 627 & 1.531 .57 & 4 & 458,502 & $44 \mid 1.7$ & 5 & $20.1 / 20.7$ & \\
\hline \multirow{6}{*}{$\begin{array}{c}\text { 炤 } \\
\text { 和 } \\
3 \\
\text { 年 } \\
18\end{array}$} & \multirow{2}{*}{ 乘 } & 2 歳 & 974 & $1.53,1.56$ & 3 & 419,472 & 531.7 & 5 & 19. & \\
\hline & & 3 歳 & 504 & $|1.51| 1.55^{i}$ & 4 & 398,451 & $53] 1.7$ & 6 & .3 & \\
\hline &  & 棓尔尔均 & 1,478 & 1.521 .56 & 4 & 4'1 465 & 541.7 & 5 & & 0 \\
\hline & \multirow{3}{*}{ 䫧 } & 2 域 & 425 & $1.54,1.57$ & 3 & \begin{tabular}{l|l}
461 & 503 \\
\end{tabular} & $42 \mid 1.77 \div .82$ & o. & 20. & 0.6 \\
\hline & & 3 蔵 & 172 & 1.52 & 3 & $434 \quad 479$ & $45 \mid 1.741 .80$ & 6 & 19.620 .3 & 0.7 \\
\hline & & 計及午均 & 597 & 1.531 .57 & 4 & $453 \quad 496$ & \begin{tabular}{l|l}
43 & 1.771 .82 \\
\end{tabular} & 5 & 19 & 0.6 \\
\hline \multirow[b]{2}{*}{ 昭 } & \multirow[t]{2}{*}{ 乘 } & 2 陚 & 830 & 1.521 .55 & 3 & 419472 & 531.741 .79 & 5 & $19.1[19.7$ & 0.6 \\
\hline & & 3 筬 & & & & $398^{\circ} 451$ & 5 & 6 & & \\
\hline
\end{tabular}




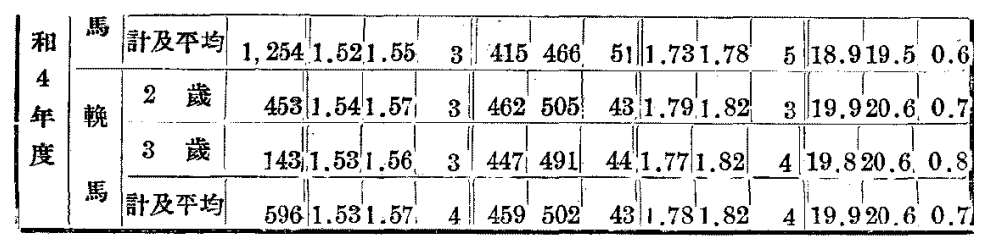

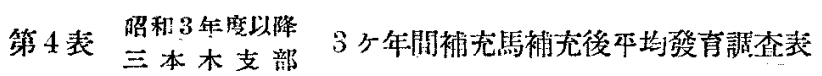



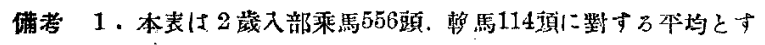

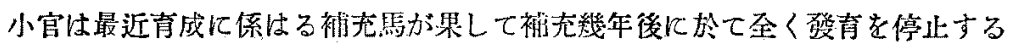
やの材料は不幸にして未だ之れを得ざるも 補无後第 1 年に於て大部の發育をな すべきことは何人と踓も不定すること能はざるぺし。殊に昭和 3 年度以隆三本末 支部補充馬に就て見るに㙏熟なるべき乘馬に於て補充後の發育體昌漸く 3 粴にし

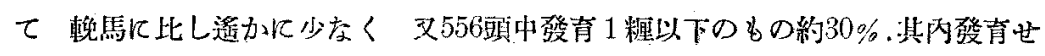

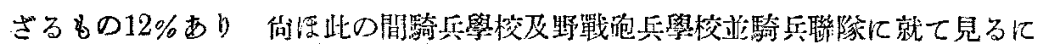
平均發育 2 、粯にして全く發育せざるもの18\%あり。


000000000000000000000000000000000000

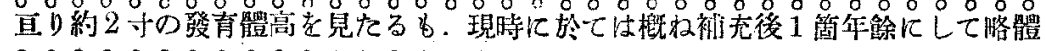


のと認めらる 你て袓充部の亩成が昔特に比し如何に進步したるか子證するに足 るべ゚。



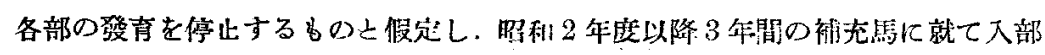
時よりの鋷育百分比を求むれば第 5 表の如し。 


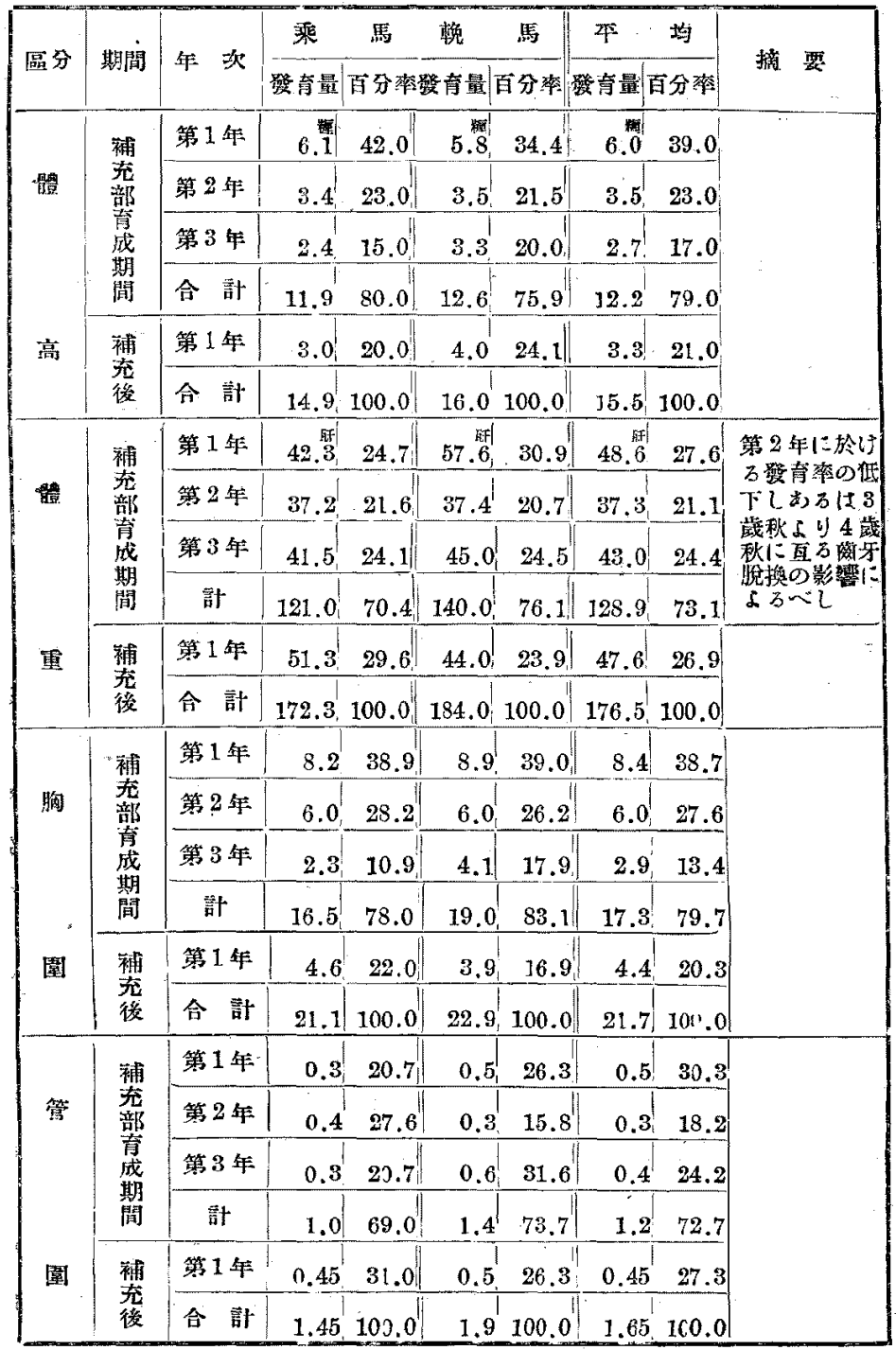

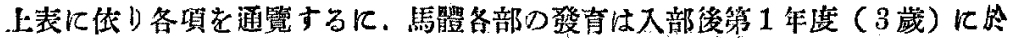

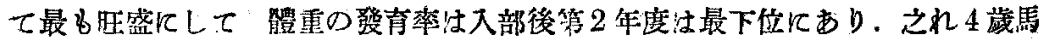




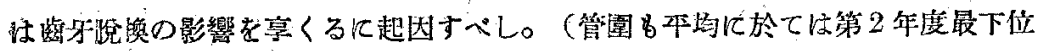
にあるb乘馬は第 2 年度に於て最も發育しもるを以て全般的に通和る老得利) 故

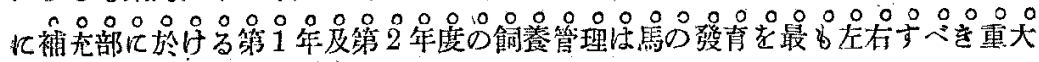

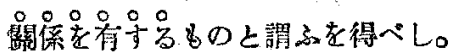

\section{3. 軍馬補充部保管馬に對する運動の基準}

皘極的鍤鍊を要求しある今日，雪馬補充部保管馬に對する運動度如们なる程度 迄之れを荘求實施せしむるを可とするやは吾人の最も研究を要すべ重大閶題に して 醫學上に於ても18歲以下の青少年に劇動を䜠するは人體發育上有害なり之

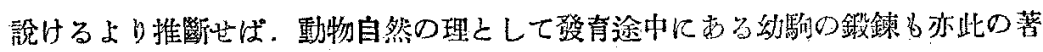
意老肝要之すべし．今．馬の骨格發育の狀態を見るに芒の如し。

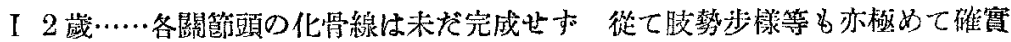
性を缺く。

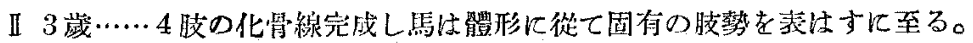

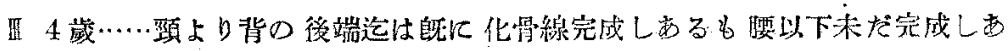

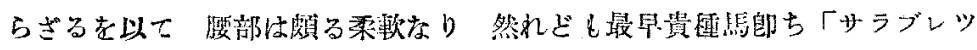







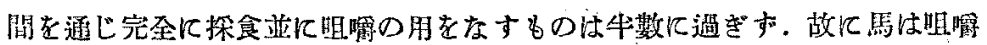

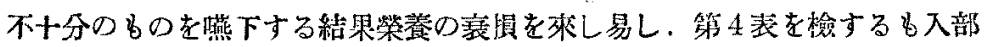
後第 2 年度に於ける體重增州率が各期を通じ最低位にあるを以て見れば自ら 首肯せらるこ゚し。

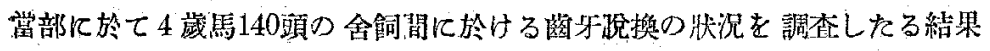
左表の如L。

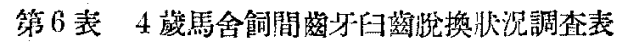

\begin{tabular}{|c|c|c|c|c|c|c|c|c|c|c|}
\hline \multicolumn{3}{|c|}{ 下䫓第 1 日夙 } & \multicolumn{3}{|c|}{ 上䫑第 1 日曾 } & \multicolumn{3}{|c|}{ 下影管 2 日菌 } & \multicolumn{2}{|c|}{ 上顎管 $2 \mathrm{FH}$} \\
\hline 11 月下旬1 & 12 旬运下 & 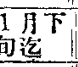 & 12 旦下 & 旬昜点 & $\begin{array}{l}2 \text { 是下 } \\
\text { 旬造 }\end{array}$ &  & $\begin{array}{l}2 \text { 月下 } \\
\text { 旬论 }\end{array}$ & 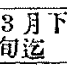 & 够汽 & $\begin{array}{l}3 \text { 昌下 } \\
\text { 祭迄 }\end{array}$ \\
\hline $14 \%$ & $60 \%$ & $26 \%$ & $8 \%$ & $80 \%$ & 23 & $12 \%$ & $75 \%$ & $13 \%$ & $25 \%$ & $75 \%$ \\
\hline
\end{tabular}




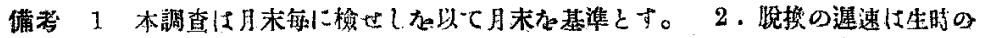

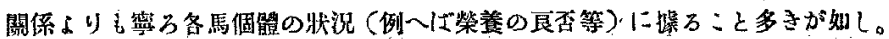
3. 3 月末に第 1 日绦未梲換のもの尚に8頭むり。

前表の如く䐋換期間は全馬を通じ約 5 万月に亘り舍鸰期間の10分D 8 は此

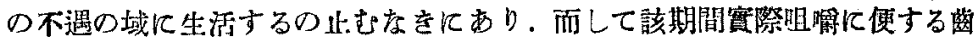

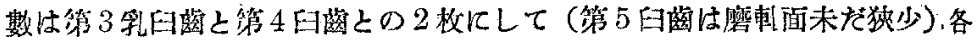

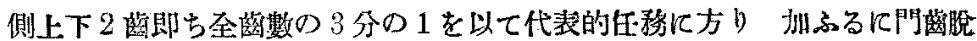

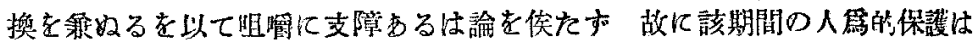
紫要事項にして明欎容易なる司料を給する必要あるや勿論なり。

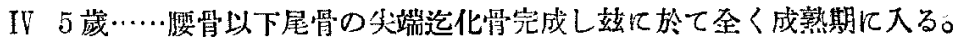


る注意の許に激行世ざれば 4 䒝重要損徵多發の原因となり 反て天廢に陷らしむ

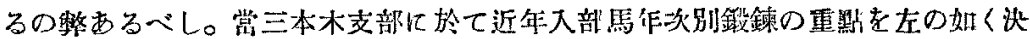

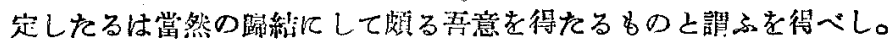

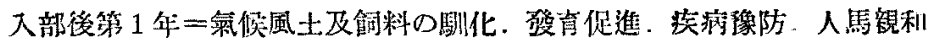

$$
\text { 馿碇の用上 }
$$

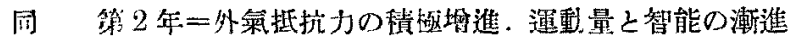

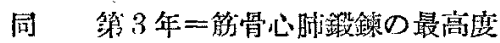



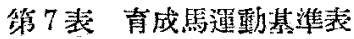

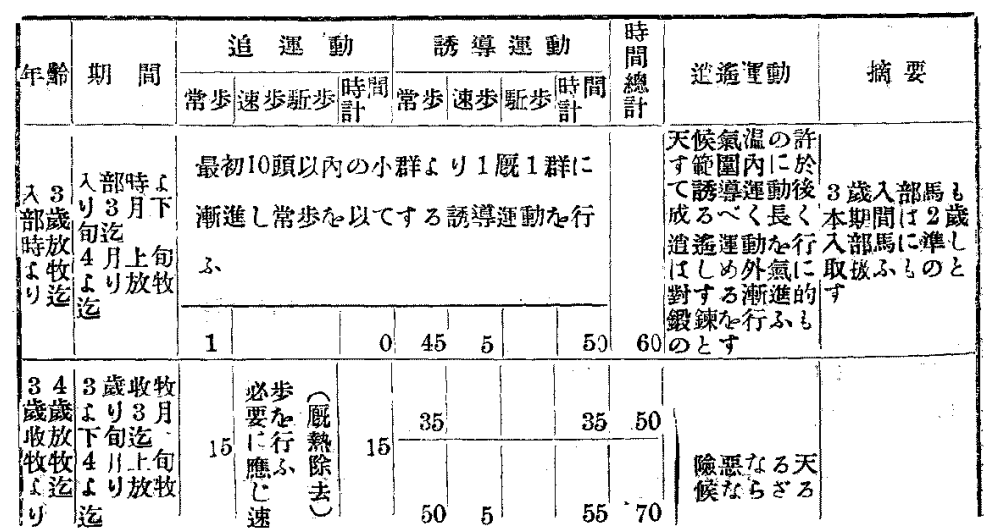




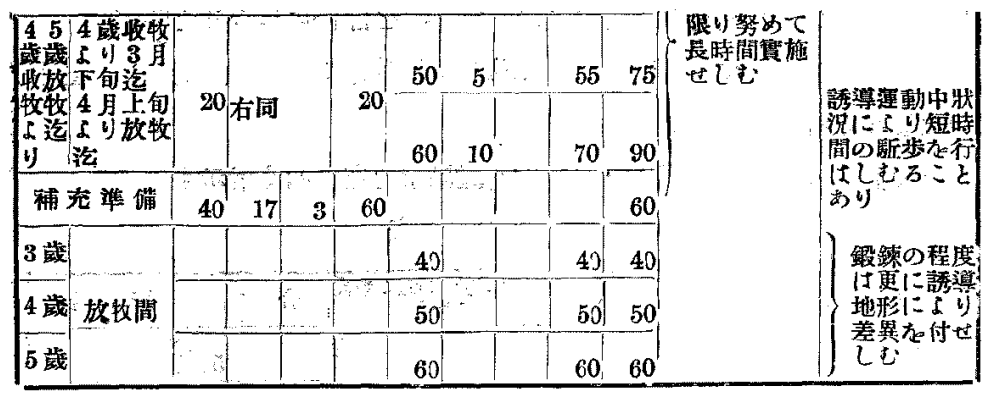

\section{4. 飼量の基準研 究}



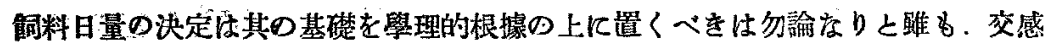

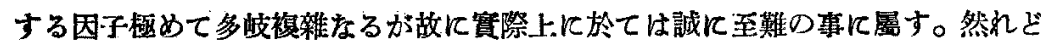
の馬の飼料に關しては一般家音飼養の原理火準據して先づ學理上必要とする養價

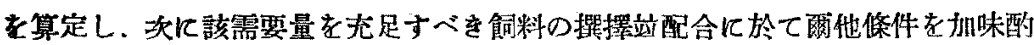
量し按配宜しきを得せしむれげ可なり。而して其要䭛に關しては大正15年度軍馬 補态部麦部長會同の際配布せられをる陸軍獸醫學校研究に係はる「軍馬補充部の

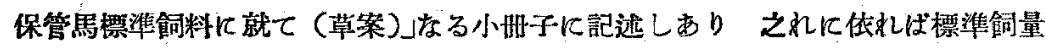
決定に着眼すべき要件としてたの諸項を揭げあり。

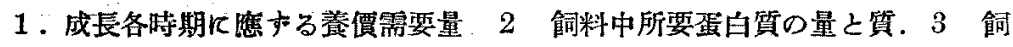
料の容積及脂肪含量 4 ，無機成分の需要量。5 副䒅素「ヴイターミン」

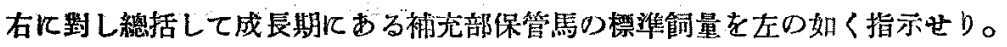

\begin{tabular}{|c|c|c|c|}
\hline 重 & 所要澱粉供 & 固形物全量 & $\begin{array}{l}\text { 可渻化蛋自所要 } \\
\text { 量(最少限) }\end{array}$ \\
\hline 500 & $5.61^{\mathrm{gf}}$ & \multirow{5}{*}{$9--11$} & 0.58 \\
\hline 450 & 5.26 & & 0.53 \\
\hline 400 & 4.88 & & 0.48 \\
\hline 350 & 4.52 & & 0.43 \\
\hline 300 & 4.14 & & 0.38 \\
\hline
\end{tabular}


又頌る困難なる闒題なり，以下之れに對し更に具體的に研究せんとす。 




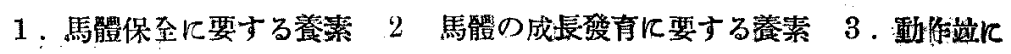
勞役江要する飬素。

之れに對し標潐創料草案に於ては所要激粉價在の如く指示す。

$$
\text { 第 } 9 \text { 表 }
$$

\begin{tabular}{|c|c|c|c|c|c|c|c|}
\hline 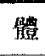 & 重 & $E$ E & E長に & 澇役 & 合 & 計 & 嚆 。要 \\
\hline & $\begin{array}{r}\mathrm{Iff}_{\mathrm{O}} \\
\end{array}$ & 3.30 & 1.00 & 1.31 & & 5.61 & \\
\hline & 450 , & 3.08 & 1.00 & 1.18 & & 5.26 & \\
\hline & 400 & 2.84 & 1.00 & 1.04 & & 4.88 & 4 乃到 5 啙 \\
\hline & 350 & 2.60 & 1.00 & 0.92 & & 4.52 & 2 乃至 3 歳 \\
\hline & 300 & $2.35^{\dagger}$ & 1.00 & 0.79 & & 4.14 & \\
\hline
\end{tabular}

次に賞部育成馬の過去 5 年閒の鲭重の本均は左表の如し。

第 10 表

\begin{tabular}{|c|c|c|c|c|c|c|c|c|c|}
\hline 年 & 齢 & 10 म & 31 月 & 12月 & 1 月 & 2 月 & 3 月 & 4月 & 5 月 \\
\hline 3 &  & $\begin{array}{l}625 \\
62\end{array}$ & 337 & 386 & 340 & 352 & 358 & 363 & 370 \\
\hline 4 & 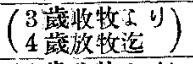 & 382 & 386 & 385 & $394_{4}$ & 396 & 398 & 402 & 406 \\
\hline 5 & 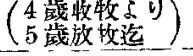 & 415 & 422 & 424 & 427 & 436 & 430 & 433 & 439 \\
\hline 補充 & 僙(收收後 1 ケ月 & & 455 & & & & & & \\
\hline
\end{tabular}

上表に基妾運動基準表（第7 表）の各期閒に應ずる平均體重在の如く概定し 所要潠粉價を求めんとす

\begin{tabular}{|c|c|c|c|c|}
\hline 3 啙 & $\begin{array}{l}\text { 自 } 2 \text { 歳入部 } \\
\text { 至 } 3 \text { 月下旬 }\end{array}$ & 425 酎 & $\begin{array}{l}\text { 自 } 4 \text { 月上旬 } \\
\text { 至放伩 }\end{array}$ & $365^{\text {咙 }}$ \\
\hline 4 歲 & $\begin{array}{l}\text { 自 } 3 \text { 歳收牧 } \\
\text { 至 } 3 \text { 月下旬 }\end{array}$ & $390^{\text {兓 }}$ & $\begin{array}{l}\text { 自 } 4 \text { 月上旬 } \\
\text { 至救敃 }\end{array}$ & $400^{\text {䣶 }}$ \\
\hline 5 歳 & $\begin{array}{l}\text { 自 } 4 \text { 歳收牧 } \\
\text { 至 } 3 \text { 月下旬 }\end{array}$ & $425^{\text {酐 }}$ & $\begin{array}{l}\text { 自 } 4 \text { 月上旬 } \\
\text { 至放呚 }\end{array}$ & $435^{\text {酐 }}$ \\
\hline \multicolumn{2}{|c|}{ 補充準倩 } & $455^{\text {每 }}$ & & \\
\hline
\end{tabular}

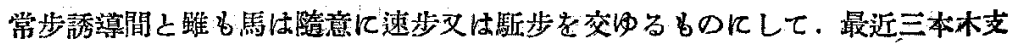
部調查にかかる馬群常步誘望間に於ける各馬 
の如く實に千差萬别の行動をなすを以て一ぬ之等の行動を計算する時は頗る繁雜

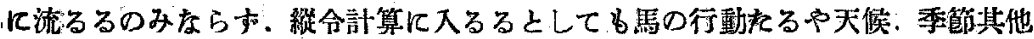

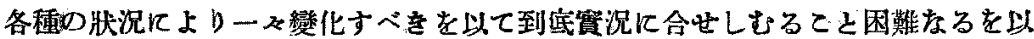
て. 其の近似數を得ることとし常步運動中左の荃に平均速步を卒ゆるものとして 常步より削除速步に加算せり。

3 歳 $10 \% 4$ 歳 $8 \% 5$ 藏 $7 \%$

\section{第11表 傌群常齿誘導に於 平均實動表}

\begin{tabular}{|c|c|c|c|c|c|c|c|c|c|}
\hline \multirow{2}{*}{ 年敬 } & \multirow{2}{*}{ 場 所 } & \multirow{2}{*}{ 各群馬數 } & \multicolumn{2}{|c|}{ 實 } & \multicolumn{2}{|c|}{ 度 } & \multicolumn{2}{|r|}{ 分 } & 茶 \\
\hline & & & 常齿 & 逨歩 & 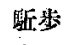 & 暍 & 常步 & 速歩 & 馸类 \\
\hline 3 & 構內運動晹 & 60 & 3.631 & 342 & 3 & 4.000 & 90.0 & 8.5 & 1.5 \\
\hline 4 & 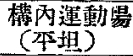 & 120 & 3.691 & 280 & 2 & 4.000 & 92.3 & 7.0 & 0.7 \\
\hline 5 & (不蜶) & 12 & 3.727 & 250 & 2 & 4.000 & 98.3 & 6.2 & 0.6 \\
\hline
\end{tabular}



2. 本表代4 月來枯草㭙の測定とす

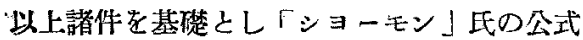

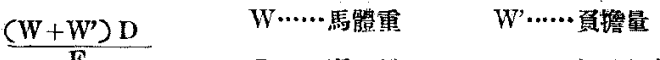

$$
\begin{aligned}
& \text { D……距 雜 F ……抵抗係數 }
\end{aligned}
$$

老適用し抵抗係数を常步 $\frac{1}{18}$ 速步 $\frac{1}{9.5}$ 駘步 $\frac{1}{7}$ として計算するとをは第12表つ如し。 第12表 有成䵭動作泣に勞役に對する養價調查表

\begin{tabular}{|c|c|c|c|c|c|c|c|c|c|}
\hline \multirow[t]{2}{*}{ 期 } & \multirow[t]{2}{*}{ 間 } & \multirow{2}{*}{ 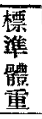 } & \multicolumn{2}{|c|}{ 傕 } & 動 & & 量 & 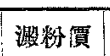 & \multirow[b]{2}{*}{ 摘 } \\
\hline & & & 步度 &  & 䚁由運 & (棓) & 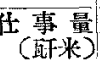 & \begin{tabular}{|c|} 
所要量 \\
(西)
\end{tabular} & \\
\hline \multirow{4}{*}{$\begin{array}{l}\text { 入 } \\
\text { 部 } \\
\text { 時 } \\
\text { よ } \\
\text { ij }\end{array}$} & \multirow{4}{*}{ 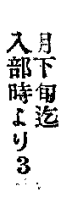 } & \multirow{4}{*}{340} & 常步 & 2.430 & 3.852 & 6.282 & 28.660 & & \multirow{4}{*}{ 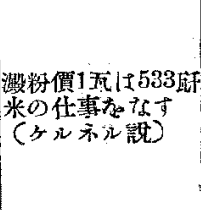 } \\
\hline & & & 速歩 & 270 & 1,021 & 1.291 & 46.204 & & \\
\hline & & & 馸歩 & & 1.855 & 1.855 & 9.100 & & \\
\hline & & & 計 & & & & 254.964 & 478 & \\
\hline
\end{tabular}






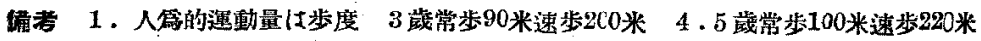

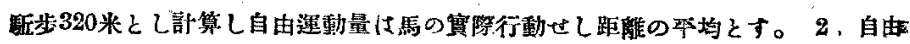
渾動量は最活三本木支部に於て調查したるるのわ基集とす。

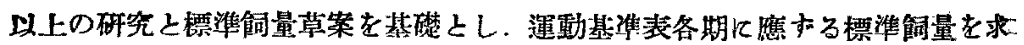
されば第13.第14表の如し。 
第 13 表

\begin{tabular}{|c|c|c|c|c|c|c|c|}
\hline 期 & 間 & 期，間 & 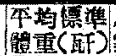 & $\begin{array}{l}\text { 保全に } \\
\text { (酐) }\end{array}$ & 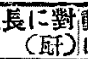 & 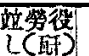 & 計 \\
\hline & (4) & 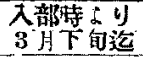 & 340 & 2.558 & 1.000 & 0.478 & 4.036 \\
\hline & 牧迄 & $\begin{array}{l}\text { 3月上旬 } \\
\text { 数牧汽 }\end{array}$ & $365^{\top}$ & 2.698 & 1.000 & 0.679 & 4.377 \\
\hline & 比より &  & 390 & 2.800 & 1.000 & 0.646 & 4.446 \\
\hline & 较迄 & 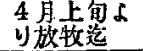 & 400 & 2.825 & 1.000 & 0.814 & 4.639 \\
\hline & 牧より & 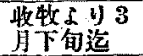 & 425) & 2.945 & 1.000 & 1.013 & 4.958 \\
\hline & 牧迄 & 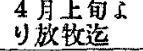 & 435 & 2.986 & 1.000 & 1.180 & 5.166 \\
\hline 補 & 充 & 準 & 455 & 3.093 & 1.000 & 1.276 & 5.359 \\
\hline
\end{tabular}

第 14 表

\begin{tabular}{|c|c|c|c|c|c|}
\hline 期 & 間 & 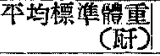 & 所琶卸粉價 & 固形物含量 & $\begin{array}{l}\text { 可消化莡白所 } \\
\text { 要量(最少量) }\end{array}$ \\
\hline 入部時より & 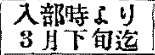 & 340 & 4.036 & $9-11$ & 0.422 \\
\hline 3 歳故牧牧 & $\begin{array}{l}4 \text { 月卡旬 } \\
\text { 敖牧迄 }\end{array}$ & 365 & 4.377 & $9-11$ & 0.447 \\
\hline 3 嵅收牧より & 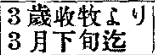 & 390 & 4.446 & $9-11$ & 0.472 \\
\hline 4 歳故牧汽 & $\begin{array}{l}4 \text { 月上旬 } \\
\text { り放收迄 }\end{array}$ & 400 & 4.639 & $9-11$ & 0.482 \\
\hline 4 歳收牧より &  & 425 & 4.958 & $9-11$ & 0.507 \\
\hline 5 瓷放牧迄 & 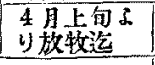 & 435 & 5.166 & $9-11$ & 0.517 \\
\hline 補充 & 準 & 455 & 5.359 & $9-11$ & 0.537 \\
\hline
\end{tabular}

\section{5. 鶬料の配合及調理}

(1) 飼 料 $\bigcirc$ 配 合

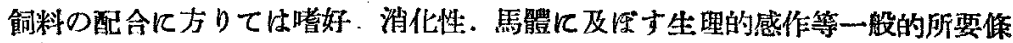
件の外，其の組成內容に閣し左記要件を完奎に具借するを要す。

1. 養㑯 (㴬粉價)十分なること。

2. 相當の容皘 (固形分量) 有寸ること。



4. 可消化脂肪含量適常なること。



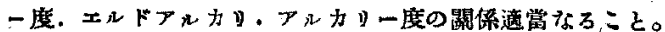

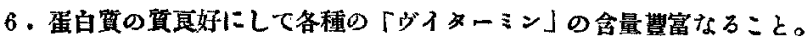


而して吾補充部に於ける各蒩飼料の組成を化學的に詳知して之れを各歲馬に隼


澱粉價を基礎として當部各歳婜各時期に應ずる飼料の配合老求しれば第15表の如 L。

第 15 表

\begin{tabular}{|c|c|c|c|c|c|c|}
\hline \multirow{2}{*}{ 期 } & \multirow{2}{*}{ 䦔 } & \multicolumn{2}{|c|}{ 平均標準所要激粉 } & \multicolumn{3}{|c|}{ 铜 料 配 合 } \\
\hline & & 骵央( & 谓 (既) & 嵒 種 & 數 量 & 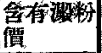 \\
\hline \multirow{3}{*}{ 入部時より } & \multirow{3}{*}{$\begin{array}{l}\text { 入部時より } \\
3 \text { 月下旬迄 }\end{array}$} & \multirow{3}{*}{340} & \multirow{3}{*}{4.036} & 濉 零 & 2.700 & 1.58 \\
\hline & & & & 草 & $9 . \cos$ & 2.58 \\
\hline & & & & 計 & & 4.10 \\
\hline \multirow{3}{*}{ 3篾放牧汽 } & \multirow{3}{*}{$\begin{array}{l}4 \text { 月_上旬よ } \\
\text { り放牧迄 }\end{array}$} & \multirow{3}{*}{365} & \multirow{3}{*}{4.377} & 㴖 雾 & 3.200 & 1,8 \\
\hline & & & & 营 & 9.000 & 2.52 \\
\hline & & & & 謨 & & $4: 39$ \\
\hline \multirow{6}{*}{3 恳牧牧士り } & \multirow{3}{*}{$\begin{array}{l}3 \text { 荿收牧より } \\
3 \text { 月下旬迄 }\end{array}$} & \multirow{3}{*}{390} & \multirow{3}{*}{4.446} & 䜩 灵 & 3.350 & \\
\hline & & & & 草 & $9.000+$ & \\
\hline & & & & 訊 & & \\
\hline & \multirow{3}{*}{$\begin{array}{l}4 \text { 月上甸より } \\
\text { 放牧迄 }\end{array}$} & \multirow{3}{*}{400} & \multirow{3}{*}{4.639} & 藏 來 & $3.65 !$ & \\
\hline & & & & 草 & 9.000 & 2.52 \\
\hline & & & & 計 & & 4.65 \\
\hline \multirow{3}{*}{ 4歳收牧より } & \multirow{3}{*}{$\begin{array}{l}4 \text { 歳收牧より } \\
\text { 3月下旬迄 }\end{array}$} & \multirow{3}{*}{425} & \multirow{3}{*}{4.958} & 䜩 麥 & 4.150 & 2.42 \\
\hline & & & & 草 & 9.00 & 2.52 \\
\hline & & & & 誁 & & 4.90 \\
\hline \multirow{3}{*}{5 瓷放牧迄 } & \multirow{3}{*}{$\begin{array}{l}4 \text { 月上旬より } \\
5 \text { 龢放牧迄 }\end{array}$} & \multirow{3}{*}{435} & \multirow{3}{*}{5.166} & 苝 零 & $4: 55)$ & 2,67 \\
\hline & & & & 草 & 9.000 & 2.52 \\
\hline & & & & 計 & & 5.19 \\
\hline \multirow{3}{*}{ 補 } & \multirow{3}{*}{ 準価 } & \multirow{3}{*}{455} & \multirow{3}{*}{5.359} & 燕 麥 & 4.900 & 2.87 \\
\hline & & & & 草 & 9.000 & $2: 52$ \\
\hline & & & & 㩐 & & $5.39]$ \\
\hline
\end{tabular}








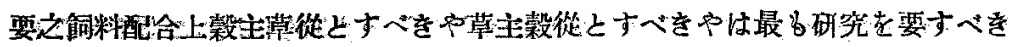
間題なり。而して補充部青成間炕馬の發清最も旺盛なる期にして此間十分の骨量

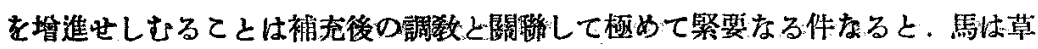

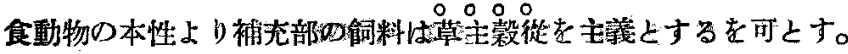

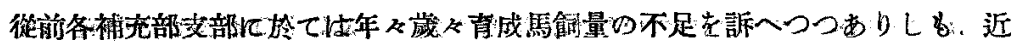

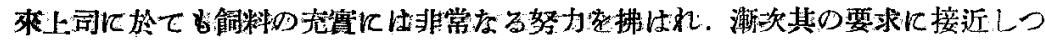


行育成舍歌馬標蕉日量を見るに大表の如く 吾人今一步の努力性終に飼料不足の 䡰を開くを要せさるに至るんし。

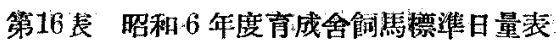

\begin{tabular}{|c|c|c|c|c|c|c|c|c|}
\hline \multicolumn{2}{|l|}{ 部 } & 名 & 憙 類: & 耕作草 & 会野草 &  & 敖 草 & 擿 \\
\hline \multicolumn{2}{|l|}{ 川 } & 上 & $\begin{array}{r}\text { 耳耹 } \\
3.00 \\
\end{array}$ & 6.70 & $\begin{array}{r}\text { 酥 } \\
1.00\end{array}$ & $\begin{array}{r}6.378 \\
\end{array}$ & $\begin{array}{r}\text { 醋 } \\
4.0\end{array}$ & \\
\hline \multirow{2}{*}{$\begin{array}{l}\text { 鈁 } \\
\text { 路 }\end{array}$} & 本 & 部 & 2.47 & 8.30 & $0.40^{\circ}$ & 6.376 & 4.0 & \\
\hline & 音 & 別: & 2.44 & 8.30 & 0.50 & $6.380^{\circ}$ & 4.0 & \\
\hline \multicolumn{2}{|l|}{+} & 旉 & 2.95 & 4.60 & 4.00 & 6.374 & 4.0 & \\
\hline \multirow{2}{*}{ 䓓 } & 本 & 部 & $\begin{array}{r}4.00 \\
3.39 \\
\end{array}$ & $\begin{array}{l}6.00 \\
4.80 \\
\end{array}$ & $\begin{array}{l}2.00 \\
2.40\end{array}$ & $\begin{array}{l}7.394 \\
6.372\end{array}$ & 4.0 & 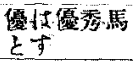 \\
\hline & t & F & 3.31 & 4.40 & 3.20 & 6.377 & 4.0 & \\
\hline \multirow{2}{*}{$\begin{array}{l}\text { 白 } \\
\text { 河 }\end{array}$} & 本 & 部 & 3.66 & 3.80 & 3.40 & 6.520 & 4. 0 & \\
\hline & 毁 治 & 澤 & 3.57 & 4.00 & $3.40_{1}$ & 6.521 & 4.0 & \\
\hline \multirow{2}{*}{$\begin{array}{l}\text { 高 } \\
\text { 錦 }\end{array}$} & 本 & 部 & $3.15^{1}$ & 4.60 & 4.20 & 6.641 & 4.0 & \\
\hline & 小 & 林 & 3.70 & 3.50 & 3.80 & 6.598 & 4.0 & \\
\hline \multicolumn{2}{|l|}{ 雄 } & 基 & 3.100 & $4: 30$ & 4.00 & 6.388 & 4.5 & \\
\hline \multicolumn{2}{|l|}{ 本 } & 坞 & 3.222 & 5.068 & 2.742 & 6.440 & 4.046 & \\
\hline
\end{tabular}


（2）飼料 ○筒 理

觡料の調理如何は馬の飼養に大なる影響を有す，從來當部に於て實施し柬りた

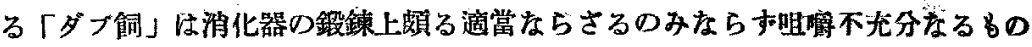

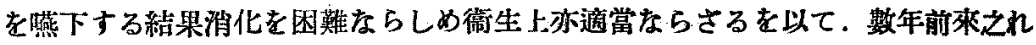

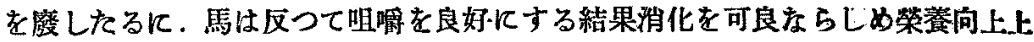
有利なるを認めたり。但し之れがをめには水與量を增加せしむるの䇺意極めて䏦


鍊に資するを可とす。切草は概ね左の程度にて可ならむ。
3 崴
2.400
4 藏 2.100
5 胔 1.800

新入馬に對する飼料の調理注細心の注意を要し. 入部當初に於ては努的て地方

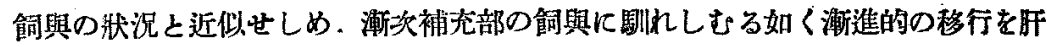

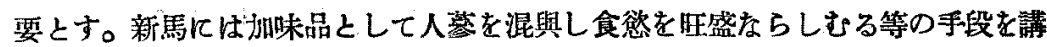
䄈ることも亦必要なり。

大豆は一度熱湯を通す程度にするとをは水浸のものよりす㖺好に適するが如 し、故に新入馬、俩弱馬等の飼與に壮此の方法に上るを可とす。

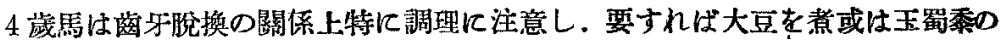

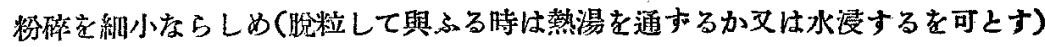
或は歌良草を飼與する等紐心の着意を㟁要とす。

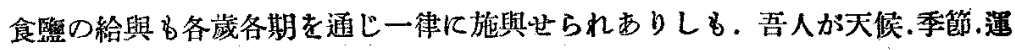

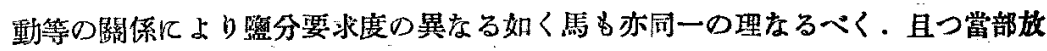

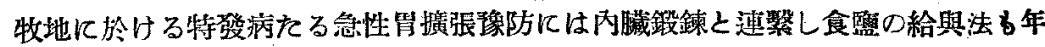
踰及各季筑江隹じ其の量老變化せしむるの要あるべをを痛感し，。昭和 4 年度より

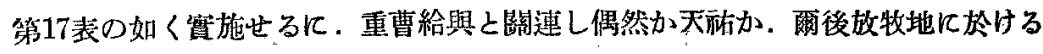
急性胃搪張（胃裂）による損耗を絕無ならしむるてとを得たり，即ち從前の一律 給與に比しては唯に效果あるを認むるてとを得ぺし。

第17表 食 留給 與 表

\begin{tabular}{|c|c|c|c|c|}
\hline 年 & 4.5 .11 月 & $\begin{array}{lcc}\text { 眰 } & 12 & \text { 肙 } \\
\end{array}$ & $\begin{array}{ccc}\text { 眰 } & 6 & \text { 月 } \\
\end{array}$ & 。均 \\
\hline 2 .万至 3 䞟 & $35^{\text {瓦 }}$ & $30^{\text {瓦 }}$ & $40^{\text {瓦 }}$ & $35^{\frac{\pi}{\pi}}$ \\
\hline
\end{tabular}




\begin{tabular}{|lr|l|l|l|l|}
\hline 4 & 歳 & 49 & 35 & 59 & 42.5 \\
\hline 5 & 歳 & 45 & 43 & 55 & 47.5 \\
\hline 本 & 均 & 40 & 35 & 48 & 42 \\
\hline
\end{tabular}

\section{6. 結 論}

要するに青成馬に對する飼料の研究は之れを要的すれば其年嵝命. 季節。運動等 飞業し



にあり．而て本閣題の如を長期飞亘り科學的研究之細心の注意と綿密なる觀察之 賽地應用とにより其成果を判定せらるごをすのにして，短期間の粗漫なる研究に

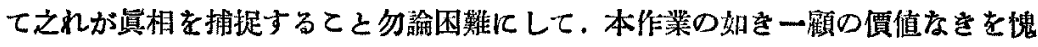

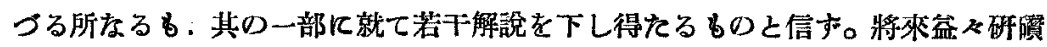
以て其の缺を補足せんとす。

(引用交䧻省路) 